Journal Universitas Muhammadiyah Gresik Engineering, Social Science, and Health International Conference (UMGESHIC)

UMGCINMATIC : $1^{\text {st }}$ Rethinking Education during Covid-19 Era: Challange and Innovation

\title{
The Effect Of Good Corporate Governance, Corporate Social Responsibility On
}

\section{Corporate Profitability}

\author{
Mirza Lailatun Ni'mah' ${ }^{1}$, Syaiful $^{2}$
}

${ }^{1}$ Student of Economic and Bussines Departement, Universitas Muhammadiyah Gresik

${ }^{2}$ Lecturer of Economic and Bussines Departement, Universitas Muhammadiyah Gresik

Email: mirza18.xiimumed@ gmail.com, syaiful@umg.ac.id

\begin{abstract}
The company's profitability is an important thing that companies use to evaluate the company's performance in a period, because profitability is a reflection of the company's ability to manage and allocate its resources. Good Corporate Governance is good corporate governance, which explains the relationship between various participants in the company that determines the direction of the company's financial performance. Disclosure of Corporate Social Responsibility is that Corporate Social Responsibility (CSR) is a form of corporate social responsibility towards the environment and the surrounding community. The purpose of this study is to prove whether Good Corporate Governance and Corporate Social Responsibility affect the company's profitability. The research was conducted on manufacturing companies in the consumer goods industry sector listed on the Indonesia Stock Exchange for the 2017-2020 period. Analysis of the data model used in this study is a multiple linear regression model using SPSS 22. Data analysis uses the classical assumption test, namely the data normality test, multicollinearity test, autocorrelation test and hiteroscedasticity test. As well as $\mathrm{t}$ test and $\mathrm{f}$ test. The results showed that there was no effect of the Board of Directors and the Audit Committee on the company's profitability. But the Independent Commissioner and CSR have a significant positive effect on profitability. Company profitability as measured by return on assets.
\end{abstract}

Keywords: Board of Directors, Independent Commissioner, Audit Committee, Corporate Social Responsibility, ROA

\section{INTRODUCTION}

With the advancement of technology that is growing, resulting in very competitive competition in the business world. If the company's performance is good, it means that the company is able to run its business efficiently, the new efficiency can be seen by calculating profitability, which is comparing the profits earned with assets, or capital that can generate these profits. ROA is one of the tools used to measure the overall level of company performance in generating profits by using the assets owned. If the ROA value is higher, it 
means that the condition of a company is getting better. For investors, profitability is used as a reference to see the company's prospects in the future, because later it will have an impact on the return to be received. As for the company itself, profitability can be used as an assessment of the effectiveness of company management. Therefore, an analytical tool is needed to assess the company's profitability, so that the company knows what factors can affect profitability so that it can maximize profits.

The value of profitability can increase with the implementation of good corporate governance or commonly referred to as Good Corporate Governance (GCG). GCG (Good Corporate Governance) is a set of regulations that function as a company control tool to generate added value for stakeholders (Wicaksono, 2014). Corporate boards have an important influence on corporate governance, because they are at the center of the company's driving ideas (Djuhriah, 2020). According to (Widjaja, 2003) companies cannot act alone, do not have the will to run themselves, therefore we need people who have the will, so that they can run the company in accordance with the aims and objectives of the company.

By carrying out the company's activities, it will definitely have a direct or indirect impact on the surrounding external environment (Indrawati, 2018). The positive impacts of industrial activities include helping to overcome problems related to poverty and unemployment, increasing state income and so on. However, the negative impact on the environment is no less. Disruption of cleanliness and various environmental pollutions are the main consequences of industrial growth which inevitably have an impact on the people living in the surrounding area. Today's business activities are not only required to seek profit or profit (bottom line), but also have to apply the triple bottom line concept. CSR is a corporate social responsibility and contributes to sustainable economic expansion by focusing on the balance between economic, social and environmental (Untung, 2009). The existence of CSR disclosure is expected by the company to gain social legitimacy from the community. It is also expected that social responsibility information disclosed in the company's annual report will be taken into consideration in decision making so that it will have a positive effect on increasing company profits. (Sayekti, 2007).

\section{RESEARCH METODE}

\subsection{Population and Sample}

The population in this study are manufacturing companies in the consumer goods sector such as food \& beverage companies, pharmaceutical companies, cosmetic companies, cigarette companies and household appliances companies listed on the Indonesia Stock Exchange in 2017-2020 by accessing the website www.idx.co.id. Sampling in this study used a nonprobability sampling method, namely purposive sampling technique. This study uses a quantitative approach. The number of samples used in this study were 29 companies with an observation period of 4 years so that the amount of data obtained was 116. however, there are 6 outliers, so the data that can be processed is 110 . The data collection method is secondary data which is the financial statements of manufacturing companies obtained from the www.idx.co.id 
site..

Operational Definition and Measurement of Variables

\subsection{Operational Definition and Measurement of Variables}

\subsubsection{Profitability}

Profitability is a ratio to measure the performance of a company in generating profits in a certain period. The financial performance of a company can be assessed using profitability. Profitability shows the performance of a company to generate profits so that it can affect investment decision making (Rumapea, 2017). In this study, profitability is proxied by ROA (Return On Assets)..

\section{ROA : Net profit after tax $\times 100 \%$ \\ Total asets}

\subsubsection{Board Of Director}

The Board of Directors is an internal company organ or party entrusted with acting in managing the company in achieving the company's goals and interests. In order for effective decisionmaking to take place, the number of directors must be carefully considered. The size of the board of directors is calculated based on the number of members of the board of directors in a company.

\section{Board of Director $=\Sigma$ Members of the Board of Directorsi}

\subsubsection{Independent Commissioner}

Independent Commissioners are members who are not affiliated with other members, such as the Board of Commissioners or the Board of Directors and the majority of shareholders. Independent Commissioners are appointed by external parties appointed through the General Meeting of Shareholders.

$\mathrm{DKI}=\underline{\text { Number of Independent commissioner }}$

Total of commissioner

\subsubsection{Diclosure Corporate Social Responsibility}

CSR disclosure is measured by the CSRDI (Corporate Social Responsibility Disclosure Index) proxy based on the Global Reporting Initiative (GRI) indicator. Disclosure consisting of 79 items, including: economy, environment, employment, human rights, social, and product responsibility (Astuti \& Nugrahanti, 2015).

Board of Director $=\Sigma$ Members of the Board of Directorsi 
Using a dummy variable for scoring, if the specified item is found in the annual report, 1 point is given, if there is none, 0 points are given. After checking and evaluating using dummy variables, CSR measurements were then carried out. Measurement of CSR is done by adding up the measurements of the four dimensions of CSR, namely, employees, society, products, and the environment, where the measurement of the four dimensions of CSR is done by dividing the number of dummy variable scores by the number of items available, then the calculation is carried out. The calculation of the number of Corporate Social Responsibility Disclosure Index (CSRDI) is as follows:

\section{jumlah item yang diungkapkan}

\section{CSRDI =}

\section{9}

Information :

CSRDI : Corporate Social Responsibility Disclosure Index Perusahaan

\subsection{Data Anlysis Methode}

To examine the effect of the Board of Directors, Independent Commissioner, Audit Committee and CSR on company profitability, multiple linear regression analysis was used with a significance level of 5\%. To meet the requirements of a good regression model, it is necessary to test the classical assumptions, namely the normality test, multicollinearity test, heteroscedasticity test and auto correlation test and hypothesis testing.

\section{Results and Disccussion}

\subsection{Research Result}

\subsubsection{Descriptive Stastical Analysis}

Tabel 1

Descriptive Stastical

Descriptive Statistics

\begin{tabular}{|l|r|r|r|r|r|}
\hline & \multicolumn{1}{|c|}{$\mathrm{N}$} & \multicolumn{1}{c|}{ Minimum } & \multicolumn{1}{c|}{ Maximum } & \multicolumn{1}{c|}{ Mean } & \multicolumn{1}{c|}{ Std. Deviation } \\
\cline { 2 - 6 } & \multicolumn{1}{|c|}{ Statistic } & Statistic & Statistic & \multicolumn{1}{c|}{ Std. Error } & \multicolumn{1}{c|}{ Statistic } \\
\hline Dewan Direksi & 110 & 2,00 & 11,00 &, 20458 & 2,14566 \\
Komisaris Independen & 110 & 25,00 & 83,00 & 1,07400 & 11,26424 \\
Komite Audit & 110 & 3,00 & 6,00 &, 03345 &, 35086 \\
CSR & 110 &, 025 &, 620 &, 011866 &, 124446 \\
ROA & 110 &, 05001 & 46,51540 &, 78827355 & 8,26748270 \\
Valid N (listwise) & 110 & & & & \\
\hline
\end{tabular}

Source: SPSS 2021 Output Results

Based on the results obtained from the SPSS output shown in the table above, it can be concluded that:

1. The X1 variable, namely the Board of Directors has the lowest value of 2 and the highest value of 11 with a standard deviation of 2.114586 .

2. Variable $X 2$, namely Independent Commissioner has the lowest value of 25 and the highest value of 83 with a standard deviation of 11.26424 . 
3. The X3 variable, namely the Audit Committee has the lowest value of 3 and the highest value of 6 with a standard deviation of 0.35086

4. Variable X4 CSR disclosure has the lowest value of 0.025 and the highest value of 0.62 with a standard deviation of 0.124446 .

The lowest value of ROA is 0.05001 and the highest value is 46.51540 with a standard deviation of 8.26748270 .

\subsubsection{Uji Asumsi Klasik}

The following are the results of the Kolmogrov Smirnov Test :

Tabel 2

Kolmogorov Sminov (K-S)

\begin{tabular}{|c|c|c|}
\hline \multicolumn{3}{|c|}{ One-Sample Kolmogorov-Smirnov Test } \\
\hline & & Unstandardized Residual \\
\hline $\mathrm{N}$ & & 110 \\
\hline Normal Parameters ${ }^{\mathrm{a}, \mathrm{b}}$ & Mean & 0000000 \\
\hline & Std. Deviation & 7,19387543 \\
\hline Most Extreme Differences & Absolute & 075 \\
\hline & Positive & 075 \\
\hline & Negative &,- 044 \\
\hline Test Statistic & & 075 \\
\hline Asymp. Sig. (2-tailed) & &, $162^{\mathrm{c}}$ \\
\hline
\end{tabular}

Sumber : Hasil Output SPSS, 2021

From table 2 it can be seen that the Kolmogorov-Smirnov calculation results show a significance value of 0.162 which means above 0.05 . Thus, it can be concluded that the regression model is feasible to use because it meets the assumption of normality or it can be said that the research data is normally distributed.

The following are the results of the Multicollinearity Test:

Tabel 3

\section{Multicollinearity Test}

Coefficients $^{\mathrm{a}}$ 


\begin{tabular}{|c|c|c|c|c|c|c|c|c|}
\hline \multirow[b]{2}{*}{ Mode } & & \multicolumn{2}{|c|}{$\begin{array}{l}\text { Unstandardized } \\
\text { Coefficients }\end{array}$} & $\begin{array}{l}\text { Standardized } \\
\text { Coefficients }\end{array}$ & \multirow[b]{2}{*}{$\mathrm{t}$} & \multirow[b]{2}{*}{ Sig. } & \multicolumn{2}{|c|}{$\begin{array}{l}\text { Collinearity } \\
\text { Statistics }\end{array}$} \\
\hline & & B & Std. Error & Beta & & & $\begin{array}{c}\text { Tolera } \\
\text { nce }\end{array}$ & VIF \\
\hline \multirow[t]{5}{*}{1} & (Constant) & 2,002 & 6,832 & & ,293 & ,770 & & \\
\hline & Dewan Direksi &, 580 & 358 & 150 & 1,620 & , 108 & ,836 & 1,196 \\
\hline & $\begin{array}{l}\text { Komisaris } \\
\text { Independen }\end{array}$ & ,249 &, 071 &, 340 & 3,527 & ,001 & ,778 & 1,285 \\
\hline & Komite Audit & $-2,767$ & 2,021 &,- 117 & $-1,369$ &, 174 & ,980 & 1,021 \\
\hline & CSR & 11,634 & 5,972 &, 175 & 1,948 & ,054 & ,892 & 1,121 \\
\hline
\end{tabular}

a. Dependent Variable: ROA

Source: SPSS Output Results, 2021

Based on table 3, it can be seen that the tolerance value of the Board of Directors is $0.836>$ 0.10 and VIF is $1.196<10$. Independent Commissioner is $0.778>0.10$ and VIF $1.285<10$. The tolerance value of the Audit Committee is $0.980>0.10$ and VIF is $1.021<10$. The tolerance value of CSR disclosure is $0.892>0.10$ and VIF is $1.121<10$. The results show that all the tolerance value is more than 0.10 and the VIF value is less than 10 , then the research variable is considered to be free from multicollinearity symptoms. As the results of the analysis above, it can be stated that the variables in this study can be stated not to have multicollinearity disorders.

The following are the results of the autocorrelation test:

Tabel 4

autocorrelation test

\begin{tabular}{|l|r|r|r|r|r|}
\hline \multirow{2}{*}{ Model } & & & & & \multicolumn{1}{c|}{ Model Summary $^{\mathbf{b}}$} \\
\hline 1 & $\mathrm{R}$ & $\mathrm{R}$ Square & Adjusted R Square & $\begin{array}{c}\text { Std. Error of the } \\
\text { Estimate }\end{array}$ & Durbin-Watson \\
\hline
\end{tabular}

a. Predictors: (Constant), CSR, DD, KA, KI

b. Dependent Variable: ROA

Source: SPSS Output Results, 2021

Based on the table, it can be seen that the Durbin Watson value is 1,870 . This value is compared with the Durbin Watson statistical value (table) using a significance value of 5\%. The number of samples is $110(\mathrm{n})$ and the number of independent variables is $4(\mathrm{k}=4)$, the values of $\mathrm{dl}=1.6146$ and $\mathrm{du}=1.7651$ are obtained. The DW value of 1.870 is greater than the upper limit of du which is 1.7651 and less than 4 -du $=4-1.7651=2.2349$, so that the decision is not rejected, which means that there is no autocorrelation.

The following are the results of the Heteroscedasticity test :

\section{Tabel 5}

\section{Heteroscedasticity test}

Scatterplot

Dependent Variable: ROA 
Source: SPSS Output Results, 2021

Heteroscedasticity does not occur if, the data points spread above and below or around the number 0 , the points do not collect above and below only, the spread of data points should not form a wavy pattern, widen, narrow then widen again, the spread of the points unpatterned data. The table above shows these characteristics. So that all variables do not occur heteroscedasticity.

\subsubsection{Hypothesis Test}

The following are the results of the Multiple Linear Regression Test :

$$
\mathrm{Y}=\mathrm{a}+\mathrm{b}_{1} \mathrm{X}_{1}+\mathrm{b}_{2} \mathrm{X}_{2}+\mathrm{b}_{3} \mathrm{X}_{3}+\mathrm{b}_{4} \mathrm{X}_{4}+e
$$

Tabel 6

\section{Multiple Linear Regression Test}

\begin{tabular}{|c|c|c|c|c|c|c|c|c|}
\hline \multicolumn{9}{|c|}{ Coefficients $^{\mathrm{a}}$} \\
\hline \multirow{2}{*}{\multicolumn{2}{|c|}{ Model }} & \multicolumn{2}{|c|}{$\begin{array}{l}\text { Unstandardized } \\
\text { Coefficients }\end{array}$} & \multirow{2}{*}{$\begin{array}{c}\text { Standardized } \\
\text { Coefficients }\end{array}$} & \multirow[b]{2}{*}{$\mathrm{t}$} & \multirow[b]{2}{*}{ Sig. } & \multicolumn{2}{|c|}{ Collinearity Statistics } \\
\hline & & $\mathrm{B}$ & Std. Error & & & & Tolerance & VIF \\
\hline 1 & (Constant) & 2,002 & 6,832 & & ,293 &, 770 & & \\
\hline & Dewan Direksi &, 580 & 358 &, 150 & 1,620 & 108 & 836 & 1,196 \\
\hline & Komisaris Independen & 249 & ,071 & ,340 & 3,527 & ,001 & ,778 & 1,285 \\
\hline & Komite Audit & $-2,767$ & 2,021 &,- 117 & $-1,369$ &, 174 & ,980 & 1,021 \\
\hline & CSR & 11,634 & 5,972 & ,175 & 1,948 & 054 & 892 & 1,121 \\
\hline
\end{tabular}

a. Dependent Variable: ROA

Source: SPSS Output Results, 2021

Source: SPSS Output Results, 2021

$$
\mathrm{Y}=2,002+0,580 \mathrm{X}_{1}+0,249 \mathrm{X}_{2}-2,767 \mathrm{X}_{3}+11,634 \mathrm{X}_{4}+e
$$

From the results of the multiple linear regression equation above, it can be interpreted as follows: 
1. The constant value of 2.002 means that if the Board of Directors (X1), Independent Commissioner (X2), Audit Committee (X3) and Corporate Social Responsibility disclosure (X4) the value is 0 , then the profitability $(\mathrm{Y})$ value is increased by 2.002 .

2. The regression coefficient of the Board of Directors (X1) of 0.580 states that if the Board of Directors (X1) has increased by 1 unit and other variables are considered constant, then Profitability (Y) has increased by 0.580 .

3. Independent Commissioner regression coefficient (X1) of 0.249 states that if the Independent Commissioner has increased by 1 unit and other variables are considered constant, Profitability (Y) has increased by 0.249 .

4. The regression coefficient of the Audit Committee $\mathrm{X} 3$ is -2.767 which states that if the Audit Committee has increased by 1 unit and other variables are considered constant, the profitability will decrease by -2.267 .

5. The regression coefficient of Corporate Social Responsibility disclosure is 11,634 which states that if the disclosure of Corporate Social Responsibility has increased by 1 unit and other variables are considered constant, then profitability $(\mathrm{Y})$ has increased by 11,634 .

The following are the results of the coefficient of determination $\left(\mathrm{R}^{2}\right)$ test:

\section{Tabel 7}

coefficient of determination $\left(\mathrm{R}^{2}\right)$ test

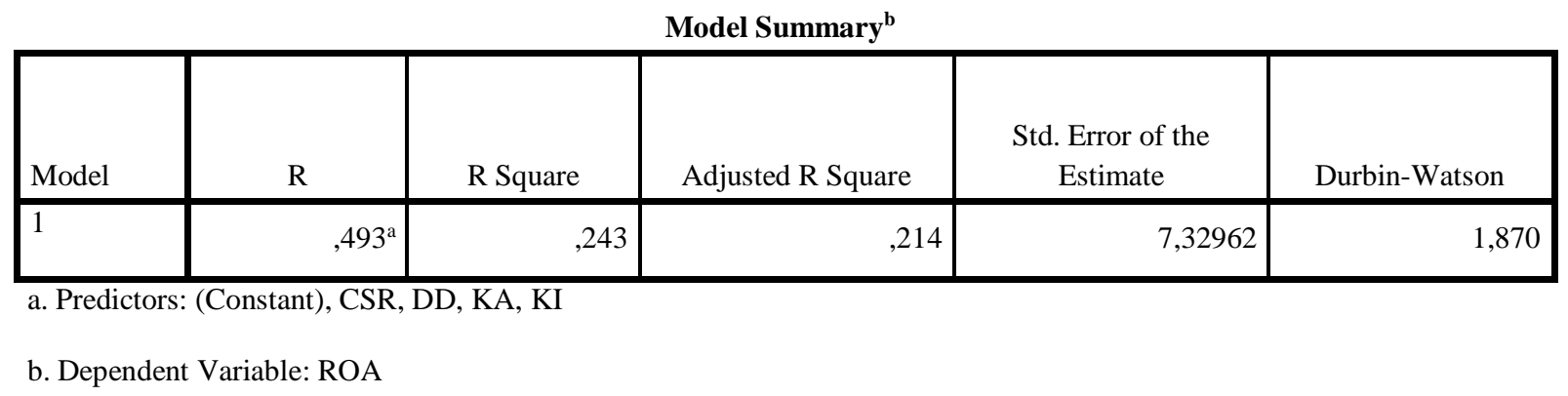

Source: SPSS Output Results, 2021

From the results of the regression output obtained the value of Adjusted R square (R2) of 0.214. This value indicates that the magnitude of the influence of the independent variable on the dependent variable is 0.214 or $21.4 \%$. Thus, there are other variables that also influence the company's profitability, which is $78.6 \%$ (obtained from $100 \%-21.4 \%=78.6 \%$ ).

The Following are the results of the partial t-test:

Tabel 8 partial t-test 


\begin{tabular}{|c|c|c|c|c|c|c|c|c|}
\hline \multirow{2}{*}{\multicolumn{2}{|c|}{ Model }} & \multicolumn{2}{|c|}{$\begin{array}{l}\text { Unstandardized } \\
\text { Coefficients }\end{array}$} & \multirow{2}{*}{$\begin{array}{c}\text { Standardized } \\
\text { Coefficients }\end{array}$} & \multirow[b]{2}{*}{$\mathrm{t}$} & \multirow[b]{2}{*}{ Sig. } & \multicolumn{2}{|c|}{ Collinearity Statistics } \\
\hline & & B & Std. Error & & & & Tolerance & VIF \\
\hline \multirow[t]{5}{*}{1} & (Constant) & 2,002 & 6,832 & & ,293 & ,770 & & \\
\hline & Dewan Direksi &, 580 & 358 &, 150 & 1,620 & 108 &, 836 & 1,196 \\
\hline & Komisaris Independen & 249 & 071 & 340 & 3,527 & 001 &, 778 & 1,285 \\
\hline & Komite Audit & $-2,767$ & 2,021 &,- 117 & $-1,369$ & , 174 & ,980 & 1,021 \\
\hline & CSR & 11,634 & 5,972 & ,175 & 1,948 & ,054 & ,892 & 1,121 \\
\hline
\end{tabular}

a. Dependent Variable: ROA

Source: SPSS Output Results, 2021

Based on table 16 by observing column $\mathrm{t}$, sig can be explained as follows:

1. The result of tcount is 1,620 while ttable $=1,98177$, so the value of tcount $<$ ttable. $t$ table is calculated by $(\alpha / 2 ; n-k-1)$. Meanwhile, the significance value of the tcount of the Board of Directors (X1) is 0.108, meaning > 0.05. Based on these results, the hypothesis that the Board of Directors has a significant positive effect on company profitability is rejected.

2. The result of tcount is 3.527 while ttable $=1.98177$, so the value of tcount $<$ ttable. $t$ table is calculated by $(\alpha / 2 ; \mathrm{n}-\mathrm{k}-1)$. Meanwhile, the significance value of the Independent Commissioner's tcount (X2) is 0.001 meaning <0.05. Based on these results, the hypothesis which states that the Independent Commissioner has a positive and significant effect on the company's profitability is accepted.

3. The result of tcount is -1.369 while ttable $=1.98177$, so the value of tcount $<$ ttable. $t$ table is calculated by $(\alpha / 2 ; n-k-1)$. Meanwhile, the significance value of the Audit Committee's tcount (X3) is 0.174, meaning > 0.05. Based on these results, the hypothesis which states that the Audit Committee has a positive and significant effect on the company's profitability is rejected.

4. The result of tcount is 1,948 while ttable $=1,98177$, so the value of tcount $<$ ttable. $t$ table is calculated by $(\alpha / 2 ; n-k-1)$. Meanwhile, the significance value of tcount of Corporate Social Responsibility (X4) disclosure is 0.054 which means $>0.05$. Based on these results, the hypothesis that the disclosure of Corporate Social Responsibility has a positive and significant effect on company profitability is rejected.

The following are the results of the F . Statistical Test:

Tabel 9

\section{F . Statistical Test}

ANOVA $^{\mathrm{a}}$

\begin{tabular}{|c|c|c|c|c|c|}
\hline Model & Sum of Squares & $\mathrm{df}$ & Mean Square & $\mathrm{F}$ & Sig. \\
\hline Regression & 1809,337 & 4 & 452,334 & 8,420 &, $000^{b}$ \\
\hline
\end{tabular}




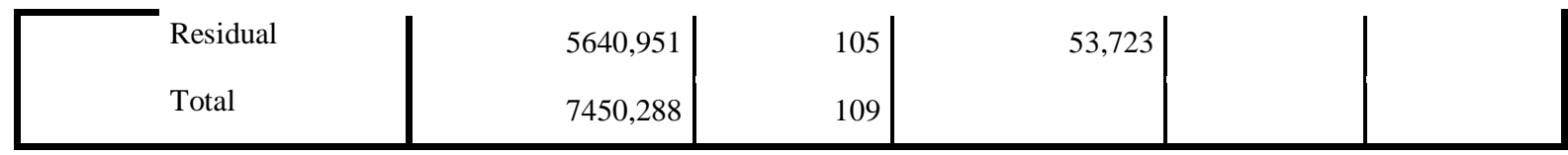

a. Dependent Variable: ROA

b. Predictors: (Constant), CSR, Dewan Direksi, Komite Audit, Komisaris Independen

Source: SPSS Output Results, 2021

Based on table 9, it can be seen that the Fcount results show a value of 8.420 which is greater than Ftable of 2.46 with a significance value of $0.000<0.05$. Ftable is obtained from $(\mathrm{k} ; \mathrm{n}-\mathrm{k})$, $(4 ; 106)$. This shows that the regression model can be used to predict the variables of the Board of Directors, Independent Commissioner, Audit Committee and Corporate Social Responsibility disclosure, it can also be said that there is a positive and significant effect on profitability simultaneously.

\section{DISCUSSION}

\subsection{The Influence of the Board of Directors on Profitability}

Based on the results of statistical analysis of research, the Board of Directors has no significant effect on increasing profitability as measured by ROA. The increasing size of the Board of Directors does not guarantee the effectiveness of performance for making the right decisions in carrying out better control functions to increase company profitability. Based on assumptions about human nature and organization in agency theory, board characteristics include the proportion of gender, board size, proportion of independent members, number of board meetings and proportion of board attendance at meetings (Endraswati et al., 2014). The size of the Board of Directors does not directly affect the profitability of the company or not. The size of the Board of Directors relates to the implications and policies of the company. The size of the Board of Directors is adjusted to the company's capabilities.

The results of this study are in accordance with research (Rimardhani et al., 2016) that the Board of Directors partially has no effect on ROA. This study is not in accordance with research (Rahmawati, 2017) in that study the Board of Directors partially has a positive and significant effect on the performance of the company proxied by ROA. With the separation of roles with the Board of Commissioners, the Board of Directors has great power over the management of resources within the company so that the Board of Directors is able to improve the company's performance.

\subsection{The Influence of Indepent Comissioners on Profitability}

Based on the results of statistical analysis of research, the Independent Commissioner has a significant positive effect on increasing profitability. The higher the number of Independent Commissioners, the ROA value also increases. The Independent Commissioner can be the mediator in overcoming agency problems because the Independent Commissioner is a member of the Board of Commissioners who is not affiliated with the management and is free from 
business relationships or other relationships that may affect the ability to act independently in the interests of the company.

The results of this study are not consistent with research (King, 2016) which says that Independent commissioners have no effect on ROA, the number of Independent Commissioners does not affect the rise and fall of profitability. This study is in accordance with research (Rimardhani et al., 2016) and (Rini \& Ghozali, 2012) that Independent Commissioners have an effect on company profitability, meaning that the higher the percentage of Independent Commissioners, the higher the level of profitability.

\subsection{The Influence of the Audit Commite on Profitability}

ommittee has no effect on increasing profitability. The results of this study are not in accordance with the hypothesis. Allegedly because the number of members of the Audit Committee can be seen from the average generated in the sample companies is 3.086957 , or three people. Judging from the Bapepam Circular Number: KEP-643/BL/2012 concerning regulation number IX.1.5 it is stated that the audit committee consists of at least three people chaired by an independent commissioner of the company with two independent external people and masters and has a background in accounting and finance. A high number of audit committees cannot guarantee the effectiveness of the audit committee's performance in supervising the company's profitability. This is indicated by a negative t value. The more the number of the Audit Committee increases, the lower the profitability. In addition, the Audit Committee is limited in its function as a tool for the Board of Commissioners so that it does not have full authority. The formation of the audit committee also tends to be only done as a formality to comply with government regulations. The results of this study are inversely proportional to research (Rini \& Ghozali, 2012), the Audit Committee has a significant positive effect on ROA profitability.

The results of this study are in accordance with research (Wibowo \& Widyatama, 2018) that the audit committee has no effect on ROA. It is also supported by research (Putra, 2015) that the formation of an audit committee in a company is only on the basis of compliance with regulations and the audit committee is less than optimal in carrying out the supervisory and control functions of company management.

\subsection{The Effect of Corporate Social Responsibility Disclosure on Profitability}

Based on the results of statistical analysis of research, CSR disclosure does not have a significant effect on increasing profitability. The higher the CSR disclosure index by the company, it does not have a significant effect on increasing the return on assets for the company's operating activities or ROA (return on assets) obtained by the company. The implementation of this CSR causes the company to incur additional costs that are not small in number (Suciwati et al., 2016). An increase in assets if not matched by an increase in profit will result in a low ROA ratio. The results of this study are in line with (Wardani, 2015) that CSR 
disclosure has no effect on ROA, the higher the CSR disclosure index by the company does not affect the increase in asset returns for the company's operating activities or ROA.

The results of this study are not in line with research (Rosdwianti \& Zahroh, 2016) and that CSR disclosure has an effect on ROA. In his research, the implementation of corporate social responsibility provides many benefits, including reducing the company's operational costs, increasing sales volume and market share, attracting potential investors through a positive image created and so on. The company's reputation is a concern for potential investors, which can be assessed from the company's profitability, so it needs to be maintained to support the company's survival.

\section{CONCLUSIONS AND LIMITATIONS}

Simultaneously, the Board of Directors, Independent Commissioner and CSR affect the company's profitability, but partially only the Board of Directors has an effect on the company's profitability.

Based on the results of the research and discussion in this study, it still has several limitations, namely the companies that are the sample of this study are only 29 companies listed on the Indonesia Stock Exchange (IDX), so they cannot represent the population of the total population. Subjective in assessing the extent of Corporate Social Responsibility disclosure. This happens because each reader sees the company's disclosure of social responsibility from a different point of view. Further research is suggested to use a corporate sustainability report that has been checked by the Global Reporting Initiative in order to reduce the subjective risk of assessing the corporate social responsibility index. And examine other characteristics of Good Corporate Governance such as the number of meetings of the Board of Directors, the number of meetings of the Independent Commissioners, the number of meetings of the Audit Committee, Managerial Ownership, and the Board of Commissioners. The number of samples used is larger so that the results obtained are more convincing. Further research is also expected to be able to use other profitability proxies, such as ROE, NPM etc.

\section{REFERENSI}

Ang, R. (1997). Buku Pintar Pasar Modal Indonesia (The Intelligent Guide to Indonesian Capital Market). Jakarta: Mediasoft Indonesia.

Astuti, C., \& Nugrahanti, Y. (2015). Pengaruh Pengungkapan Corporate Social Responsibility Terhadap Reaksi Pasar. Dinamika Akuntansi, Keuangan Dan Perbankan, Nopember 2015, 4(2), 90-105.

Ayu, P., \& Adi, W. (2013). Karakteristik Good Corporate Governance Dan Kinerja Perusahaan Manufaktur. E-Jurnal Akuntansi, 2(3), 594-613.

Djuhriah, A. (2020). Etika dan Aturan GCG Tidak Ditaati, Penyalahgunaan Jabatan oleh Eks Dirut Garuda. Kumparan.Com. https://kumparan.com/aminatun-djuhriah/etika-danaturan-gcg-tidak-ditaati-penyalahgunaan-jabatan-oleh-eks-dirut-garuda1us4oMoL2eR/full

Endraswati, H., Suhardjanto, D., \& Krismiaji. (2014). Board of Directors and Remuneration in 
Indonesian Banking. GSTF Journal on Business Review (GBR), 3(3), 40-45. https://doi.org/10.7603/s40706-014-0025-7

Indrawati, L. (2018). Pegaruh Good Corporate Governance dan Pengungkapan Corporate Social Responsibility Terhadap Nilai Perusahaan. Interciencia, 489(20), 313-335.

Istighfarin, D., Gusti, N., \& Wirawati, P. (2015). Pengaruh Good Corporate Governance Terhadap Profitabilitas pada BUMN. E-Jurnal Akuntansi Universitas Udayana, 13(2), 564-581.

J.Wild, J., K.R.Subramanyam, \& F.Halsey, R. (2005). Financial Statement Analysis. In 1 (8th ed., p. 109). Salemba Empat.

Katutari, R. A., Nur, E., \& Yuyetta, A. (2019). Pengaruh Kepemilikan Institusi, Karakteristik Dewan Komisaris Dan Komite Audit Terhadap Profitabilitas. Diponegoro Journal of Accounting, 8(3), 1-12.

Kusumadilaga, R. (2010). Pegaruh Corporate Social Responsibility Terhadap Nilai Perusahaan Dengan Profitabilitas Sebagai Variabel Moderating. In Australian Road Research (Vol. 11, Issue 2).

Lukman Syamsuddin. (2016). Manajemen Keuangan Perusahaan. RajaGrafindo Persada.

Malau, N. S., Tugiman, H., \& Budiono, E. (2018). Pengaruh Good Corporate Governance Dan Corporate Social Responsibility Terhadap Kinerja Keuangan ( Studi pada Perusahaan Manufaktur yang Terdaftar di BEI Tahun 2016 ). E-Proceeding of Management, 5(1), 583594.

Nugroho, F. A., \& Rahardjo, S. N. (2014). Analisis Pengaruh Corporate Social Responsibility Dan Karakteristik Good Corporate Governance Terhadap Kinerja Perusahaan. Diponegoro Journal of Accounting, Vol. 3 No., 1-10.

Putra, A. S. (2015). Social Responsibility Terhadap Profitabilitas Perusahaan. ( Studi Empiris pada Perusahaan Sektor Industri Barang Konsumsi yang Terdaftar di Bursa Efek Indonesia Tahun 2010-2013 ) Anggara Sa. IV.

Rahmawati, I. (2017). Pengaruh dewan direksi, dewan komisaris, komite audit dan Corporate social responsibility Terhadap kinerja keuangan perusahaan. Jurnal Akuntansi Dan Ekonomi, 2(2), 54-70.

Raja, D. H. L. (2016). Pengaruh dewan komisaris, komisaris independen, komite audit terhadap profitabilitas pada perusahaan sektor property dan real estate yang terdaftar di bursa efek indonesia (bei) tahun 2009-2014. Fakultas Ekonomi, 139-146.

Rimardhani, H., Hidayat, R., \& Dwiatmanto, D. (2016). Pengaruh Mekanisme Good Corporate Governance Terhadap Profitabilitas Perusahaan (Studi Pada Perusahaan Bumn Yang Terdaftar Di Bei Tahun 2012-2014). Jurnal Administrasi Bisnis S1 Universitas Brawijaya, 31(1), 167-175.

Rini, T. S., \& Ghozali, I. (2012). Pengaruh Pemegang Saham Institusi, Komisaris Independen, dan Komite Audit Terhadap Tingkat Profitabilitas Perusahaan. Diponegoro Journal of Accounting, 1(1), 1-11.

Rosdwianti, M. K., \& Zahroh, Z. A. (2016). Pengaruh Corporate Social Responsibility (CSR) Terhadap Profitabilitas Perusahaan ( Studi Pada Sektor Industri Barang Konsumsi Yang 
Terdaftar Di Bursa Efek Indonesia Periode 2013-2014 ). 38(2), 16-22.

Rumapea, M. (2017). Pengaruh Good Corporate Governance Terhadap Profitabilitas Perusahaan Manufaktur Yang Terdaftar Di Bursa Efek Indonesia Periode 2013-2015. Diponegoro Journal of Accounting, 3(3), 709-723.

Suciwati, D., Pradnyan, D., \& Ardina, C. (2016). Pengaruh Corporate Social Responsbility Terhadap Kinerja Keuangan (Pada Perusahaan Sektor Pertambangan di BEI Tahun 20102013). Jurnal Bisnis Dan Kewirausahaan, 12(2), 104-113.

Sukandar, P. P., \& Rahardja. (2014). Pegaruh Ukuran Dewan Direksi dan Komisaris Serta Ukuran Perusahaan Terhadap Kinerja Keuangan (Studi Empiris pada Perusahaan Manufaktur Sektor Consumer Good yang Terdaftar di BEI Tahun 2010-2012). Diponegoro Journal Of Accounting, 3(3), 689-695.

Tulung, J. E., Ekonomi, F., Bisnis, D., \& Manajemen, J. (2020). Pengaruh Good Corporate Governance Terhadap Kinerja Keuangan Bank Umum Konvensional Tahun 2014-2018. Jurnal EMBA: Jurnal Riset Ekonomi, Manajemen, Bisnis Dan Akuntansi, 8(3), 296-305. https://doi.org/10.35794/emba.v8i3.29984

Wardani, M. K. P. W. (2015). Pengaruh Pengungkapan Corporate Social Responsibility Terhadap Profitabilitas Perusahaan (Studi Empiris pada Perusahaan yang Terdaftar di BEI tahun 2010-2012). Skripsi, 107.

Wardhani, R. (2007). Mekanisme Corporate Governance Dalam Perusahaan Yang Mengalami Permasalahan Keuangan. Jurnal Akuntansi Dan Keuangan Indonesia, 4(1), 95-114. https://doi.org/10.21002/jaki.2007.05

Wibowo, A., \& Widyatama, B. (2018). Pengaruh Mekanisme Corporate Governance Terhadap Peringkat. 4(2337-3806), 11-12.

Widjaja, G. (2003). Tanggung Jawab Direksi atas Kepailitan Perseroan. PT. Raja Gravindo Persada.

Yahya, F. (2013). Pengaruh Corporate Social Responsibility Dimensi Good Corporate Governance Terhadap profitabilitas perusahaan. Journal of Chemical Information and Modeling, 53(9), 1689-1699. 